\section{Links between erosion, runoff variability and seismicity in the Taiwan orogen}

\section{Simon J. Dadson ${ }^{1}$, Niels Hovius ${ }^{1}$, Hongey Chen ${ }^{2}$, W. Brian Dade ${ }^{4}$, Meng-Long Hsieh ${ }^{2}$, Sean D. Willett ${ }^{5}$ Jyr-Ching Hu${ }^{2}$, Ming-Jame Horng ${ }^{6}$, Meng-Chiang Chen ${ }^{7}$, Colin P. Stark ${ }^{8}$, Dimitri Lague ${ }^{1}$ \& Jiun-Chuan Lin $^{3}$}

${ }^{1}$ Department of Earth Sciences, University of Cambridge, Downing Street, Cambridge, CB2 3EQ, UK

${ }^{2}$ Department of Geosciences, ${ }^{3}$ Department of Geography, National Taiwan University, No. 1, Sec. 4, Roosevelt Road, Taipei, Taiwan

${ }^{4}$ Department of Earth Sciences, Dartmouth College, Hanover, New Hampshire 03755, USA

${ }^{5}$ Department of Earth and Space Sciences, University of Washington, Seattle, Washington 98195, USA

${ }^{6}$ Water Resources Agency, Ministry of Economic Affairs, Hsin-Yi Road, Taipei, Taiwan

${ }^{7}$ Taroko National Park Headquarters, Fu-Su Village, Hualien, 972, Taiwan ${ }^{8}$ Lamont-Doherty Earth Observatory of Columbia University, Palisades, New York 10964, USA

The erosion of mountain belts controls their topographic and structural evolution $^{1-3}$ and is the main source of sediment delivered to the oceans ${ }^{4}$. Mountain erosion rates have been estimated from current relief and precipitation, but a more complete evaluation of the controls on erosion rates requires detailed measurements across a range of timescales. Here we report erosion rates in the Taiwan mountains estimated from modern river sediment loads, Holocene river incision and thermochronometry on a million-year scale. Estimated erosion rates within the actively deforming mountains are high $\left(3-6 \mathrm{~mm} \mathrm{yr}^{-1}\right)$ on all timescales, but the pattern of erosion has changed over time in response to the migration of localized tectonic deformation. Modern, decadal-scale erosion rates correlate with historical seismicity and storm-driven runoff variability. The highest erosion rates are found where rapid deformation, high storm frequency and weak substrates coincide, despite low topographic relief.

Taiwan results from collision of the Luzon arc, on the Philippine sea plate, and the Asian continental margin ${ }^{5}$ (Fig. 1). The 4-km-high mountain belt links opposite-dipping subduction systems at the Manila and Ryukyu trenches. Plate boundary obliquity has led the collision to propagate southward over the past $5 \mathrm{Myr}$, with marine terrace uplift ${ }^{6}$ and exhumation rates ${ }^{7}$ of $5-7 \mathrm{~mm} \mathrm{yr}^{-1}$. Across central Taiwan metamorphic grade increases from poorly consolidated, Upper Tertiary sediments in the Western Foothills thrust belt, through slates in the Hsuehshan and western Central ranges, to greenschist grade pre-Tertiary meta-sediments in the eastern Central Range. The subtropical climate of Taiwan, with an average of four typhoons per year ${ }^{8}$ and mean annual precipitation of $2.5 \mathrm{~m} \mathrm{yr}^{-1}$, combined with frequent earthquakes, together drive rapid mass-wasting and fluvial bedrock incision ${ }^{9,10}$.

Since 1970, river suspended-sediment discharge has been recorded at over 150 stations across Taiwan ${ }^{11}$. We have estimated average catchment-wide erosion rates ${ }^{12,13}$ from these measurements for the interval 1970-1999 (Methods; Supplementary Fig. S1a; Supplementary Table S1). Erosion rates estimated from repeat bathymetric surveys of water reservoirs (1970-1998) correlate with suspended-load estimates in nearby catchments $\left(r^{2}=0.45\right.$; Supplementary Fig. S1b), indicating that suspended sediment and bedload comprise about $70 \pm 28 \%$ and $30 \pm 28 \%$, respectively, of total river load in high mountains (uncertainties are 95\% confidence intervals).

The $30-y r$ average suspended-sediment erosion rate of Taiwan is
$3.9 \mathrm{~mm} \mathrm{yr}^{-1}$. Between 1970 and 1999, Taiwan supplied $384 \mathrm{Mt} \mathrm{yr}^{-1}$ of suspended sediment to the ocean. This represents $1.9 \%$ of estimated global suspended sediment discharge ${ }^{4}$ and yet is derived from only $0.024 \%$ of Earth's subaerial surface. Adding $30 \%$ bedload would increase the estimated erosion rate to $5.2 \mathrm{~mm} \mathrm{yr}^{-1}$ and average annual sediment yield to $500 \mathrm{Mt} \mathrm{yr}^{-1}$, although much of the bedload is trapped in floodplains before reaching the sea.

Decadal-scale erosion rates were high in the eastern Central Range and southwest Taiwan, but low in the north and west (Fig. 2a). The metamorphic core is eroding at $\sim 6 \mathrm{~mm} \mathrm{yr}^{-1}$. Erosion rates of up to $60 \mathrm{~mm} \mathrm{yr}^{-1}$ were found around active thrust faults in the south of the Western Foothills thrust belt. North and west Taiwan had lower erosion rates $\left(1-4 \mathrm{~mm} \mathrm{yr}^{-1}\right)$.

To complement these modern, catchment-scale erosion rates, we obtained reach-scale river incision rates from 25 Holocene strath terraces at 12 locations, dated using ${ }^{14} \mathrm{C}$ (Methods; Supplementary Table S2; Fig. 2b). Channel incision rates range from $1.5 \mathrm{~mm} \mathrm{yr}^{-1}$ in the north and $9 \mathrm{~mm} \mathrm{yr}^{-1}$ in the east, to over $15 \mathrm{~mm} \mathrm{yr}^{-1}$ around active structures in the Western Foothills thrust belt ${ }^{14}$.

Persistence of erosion rates over million-year timescales was assessed using new and published ${ }^{15}$ apatite fission-track data with a geothermal model to calculate exhumation rates (Methods; Fig. 2c). Samples whose fission-track age was reset in the present orogeny ( $\leq 5 \mathrm{Myr}$ ) were found in the eastern section of the thrust belt and the metamorphic core of the mountain belt. They indicate exhumation rates of $3-6 \mathrm{~mm} \mathrm{yr}^{-1}$ in the eastern Central Range

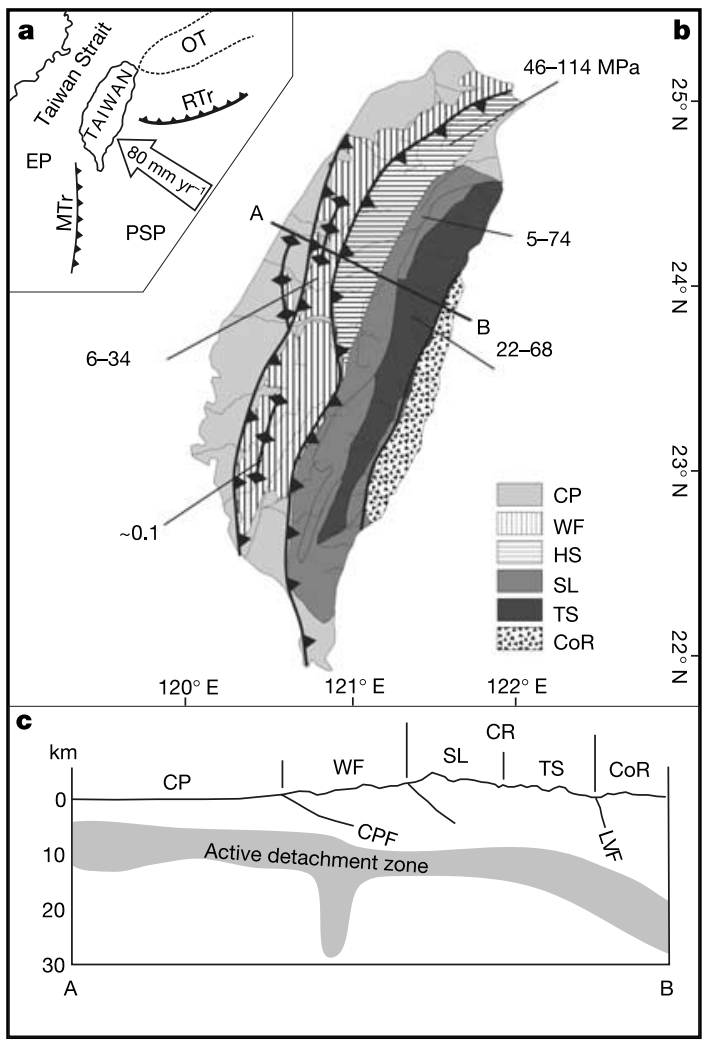

Figure 1 Location and geotectonic framework of Taiwan. a, Plate tectonics of the Ryukyu-Taiwan-Luzon area ${ }^{5}$. EP, Eurasian plate; PSP, Philippine Sea plate; MTr, Manila trench; RTr, Ryukyu trench; OT, Okinawa trough. b, Lithology ${ }^{28}$ with structures and uniaxial compressive rock strength measurements given in MPa. CP, coastal plain; WF, Western Foothills thrust belt; HS, Hsuehshan Range; SL, slate belt; TS, Tananao schist; CoR, Coastal Range. c, Schematic cross-section ${ }^{5}$ showing basal detachment zone imaged using small earthquakes ${ }^{29}$. CR, Central Range; CPF, Chelungpu fault; LVF, longitudinal valley fault. 
and $1.5-2.5 \mathrm{~mm} \mathrm{yr}^{-1}$ in the eastern thrust belt and south-central Taiwan. In contrast, unreset apatite ages from the Western Foothills thrust belt and south Taiwan reflect earlier exhumation ( $>5 \mathrm{Myr}$ ). No rate information can be obtained from unreset samples.
Taken together, our data indicate that erosion rates in the eastern Central Range were 3-6 $\mathrm{mm} \mathrm{yr}^{-1}$ across all timescales considered here, although some catchments had higher decadal erosion rates. This persistent, rapid erosion has exhumed greenschist-grade metamorphic rocks in east Taiwan. By comparison, rapid Holocene

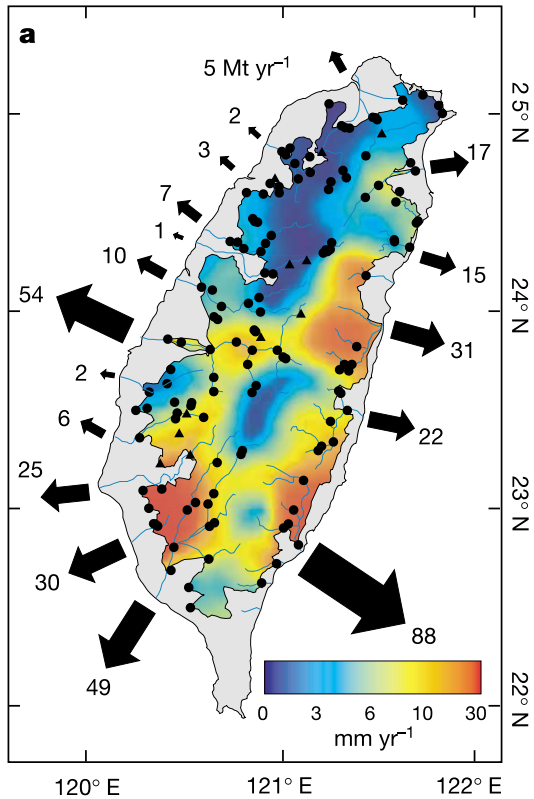

Figure 2 Erosion rates in Taiwan across multiple timescales. a, Calculated from fluvial suspended sediment observations with 5-km grid resolution, smoothed at catchment scale using a circular moving mean with $30-\mathrm{km}$ diameter. Black arrows indicate mean annual coastal suspended sediment flux from rivers draining areas greater than $400 \mathrm{~km}^{2}$. Coastal sediment fluxes are reported from hydrometric stations closest to coast. Average uncertainty of these values is $37 \%$. Black circles indicate hydrometric stations used to construct the map; triangles indicate locations of reservoirs used in reservoir fill analysis; no data are available within the grey shaded area. b. Bedrock strath incision rates (all in $\mathrm{mm} \mathrm{yr}^{-1}$ ). Values for each locality represent mean incision rate for all terraces measured at that locality. Uncertainties are one standard deviation in radiometric age and $20 \%$ in

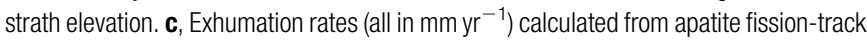
ages: red, reset; orange, partially reset; blue, unreset.

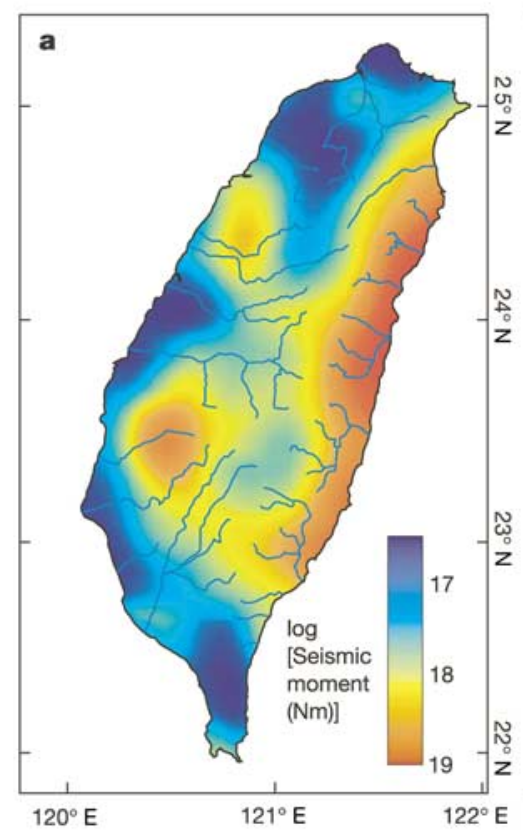

Figure 3 Seismic, hydrological and topographic controls on denudation pattern. a, Cumulative seismic moment, $M_{0}$, computed from historical record of earthquakes greater than $M_{\mathrm{w}}=5.0$, between 1900 and 1998 (that is, excluding the 1999 Chi-Chi earthquake). Where seismic moment is not reported directly, we have estimated it from the listed magnitude using a global relation ${ }^{30}$. b. Runoff coefficient of variation
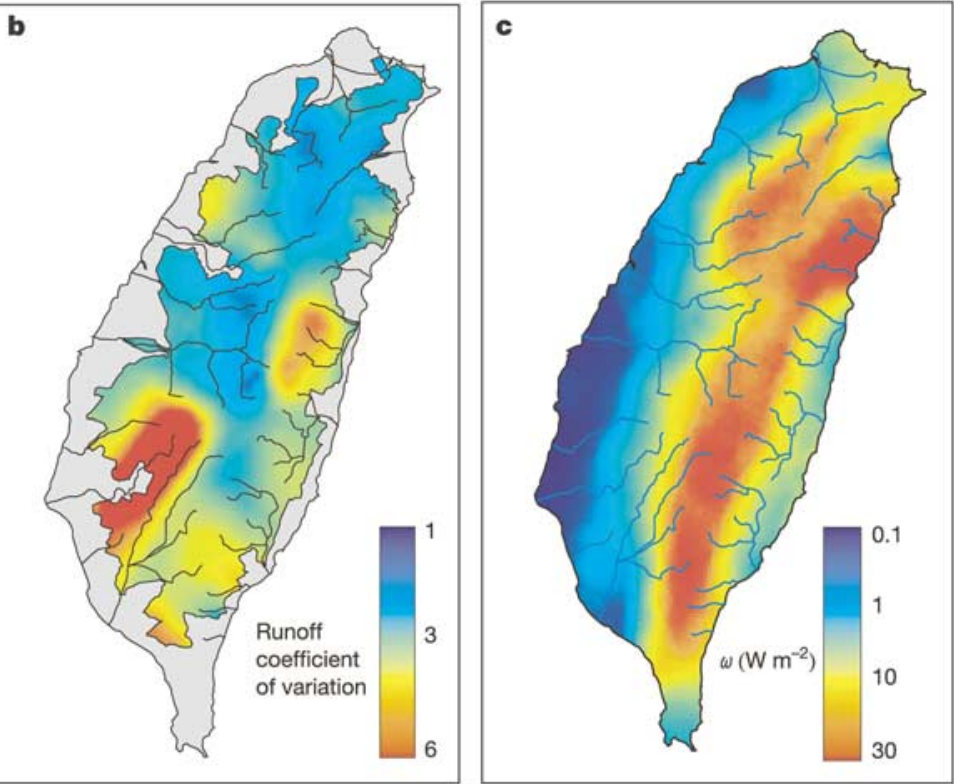

(dimensionless), defined as standard deviation of runoff divided by mean runoff. Runoff $\left(\mathrm{m} \mathrm{yr}^{-1}\right)$ was measured as average annual river discharge divided by drainage area. c, Unit stream-power $\left(\mathrm{W} \mathrm{m}^{-2}\right)$ presented at $1-\mathrm{km}$ grid resolution with $30-\mathrm{km}$ circular moving mean applied. 
river incision rates of $5-12 \mathrm{~mm} \mathrm{yr}^{-1}$, and decadal erosion rates averaging $15 \mathrm{~mm} \mathrm{yr}^{-1}$, are probably a recent feature associated with westward propagation of the thrust belt. Unreset apatite fissiontrack ages in the Western Foothills thrust belt appear to confirm this view, although thermochronometers are relatively insensitive to the shallow, largely horizontal deformation of the thrust belt. Rapid fluvial incision in the Western Foothills correlates with active, blind thrusts and fault-ramp systems in poorly consolidated PlioceneQuaternary sediments ${ }^{16,17}$, and we hypothesize that high catchmentwide erosion rates have suppressed the topographic expression of these faults.

Patterns of Holocene incision rate and decadal suspendedsediment erosion rate are broadly consistent, but with maximum values of $60 \mathrm{~mm} \mathrm{yr}^{-1}$, decadal rates systematically exceed Holocene incision rates in southwest Taiwan. Moreover, decadal erosion rates are lower than expected in the north of the Western Foothills thrust belt. Explanations include changing climate and land-use, or brevity of the hydrometric record. Palynology indicates substantial climate variation $^{18}$ across Taiwan during the Holocene, but this is unlikely to account for the north-south contrast. Growth of agriculture and urbanization may have affected erosion, although urbanization is limited to the coastal plains. Our data show no trend of increased erosion with economic development. We propose, instead, that the decadal erosion pattern reflects the location of recent climatic and seismic perturbations, superimposed on other, persistent controls on erosion.

We have evaluated controls on erosion rates in Taiwan using topographic, climatic, geomechanical and seismic databases. Spatial variability in average erosion rates can be explained to a statistically significant degree (with 95\% confidence) by (1) cumulative seismic moment release $\left(r^{2}=0.13\right.$; Fig. $\left.3 a\right)$ and (2) temporal variability in runoff $\left(r^{2}=0.27\right.$; Fig. $\left.3 \mathrm{~b}\right)$. The bulk of the remaining variation probably originates in the natural variability in mountain drainage basins. Surprisingly, no significant correlation was found between decadal erosion rates and stream power $\left(r^{2}=0.01\right.$; Fig. $\left.3 c\right)$, precipitation $\left(r^{2}=0.001\right)$, runoff $\left(r^{2}=0.03\right)$ or local relief $\left(r^{2}=0.01\right)$ (Supplementary Fig. S2). These results indicate that modern erosion rates are strongly influenced by large earthquakes and typhoons, both of which drive widespread sediment supply to channels.

Earthquakes produce sediment by rock mass shattering and landsliding ${ }^{19}$. In Taiwan there is a clear link between erosion and historical cumulative seismic moment release between 1900 and 1998 (Fig. 4a). Historical seismicity was high along the east coast and across southern Taiwan; but low in the north and west, in the far south, and in a small region of the Central Range (Fig. 3a). This pattern agrees with GPS convergence rates ${ }^{16,20}$. Across Taiwan, cumulative seismic moment release correlates linearly with decadal erosion rate over a sixfold range. Seismic sediment production is therefore an important control on erosion in Taiwan. We note, however, that the seismically driven erosion pattern may be relatively short-lived, given the along-strike uniformity of shortening across the mountain belt. The southwestern section of the thrust belt experienced eleven historic earthquakes of magnitude $M_{\mathrm{w}}>6.0$ between 1900 and 1998, whereas only three such earthquakes occurred in the north. The $1999 M_{\mathrm{w}}=7.6$ Chi-Chi earthquake may be expected to elevate erosion rates considerably in the north of Taiwan.

Sediment is also produced and mobilized by storm-triggered landslides. This is clear from the significant correlation between erosion rates and the coefficient of runoff variation, which represents storm incidence (Fig. 4b). Runoff variability is high along the east coast of Taiwan, where most incoming typhoons make landfall; it is especially high in the south of Taiwan, where typhoon passage is not obstructed by topography (Fig. 3b). We conclude that storm runoff is a first-order control on erosion rates in Taiwan, triggering primary landslides and debris flows, which flush colluvial sediment from the mountain belt.

A common assumption is that erosion rates are jointly governed by relief and average precipitation ${ }^{21,22}$. This assumption does not fit modern erosion rates in Taiwan. We have compared the observed decadal erosion pattern with stream power, a combined measure of relief and precipitation (Methods). The stream power pattern (Fig. 3c) emphasizes areas of high relief and orographic precipitation along the Central Range, where rapid exhumation has persisted longest. However, it does not match first-order features of the decadal erosion pattern, such as high erosion rates at mountain fronts, the order-of-magnitude increase from north to south, and high erosion rates around active thrusts in the southwest. We hypothesize that, over decadal timescales, stream power is not the rate-limiting control on erosion in Taiwan. This is due to intermittent storm- and earthquake-driven sediment supply, and the effect of substrate strength on topographic relief.

The effect of substrate strength was assessed using 1,114 measurements of uniaxial compressive strength at 23 sites across Taiwan (Fig. 1b; Supplementary Table S3). Rock strength varies over three orders of magnitude (0.1-253 MPa), broadly increasing with metamorphic grade from west to east, and south to north, with a drop in the alluviated depression between the Central and Coastal ranges. This trend is reflected in the relief of Taiwan, which is greatest in competent meta-sandstones and steepest in marbles and gneisses in
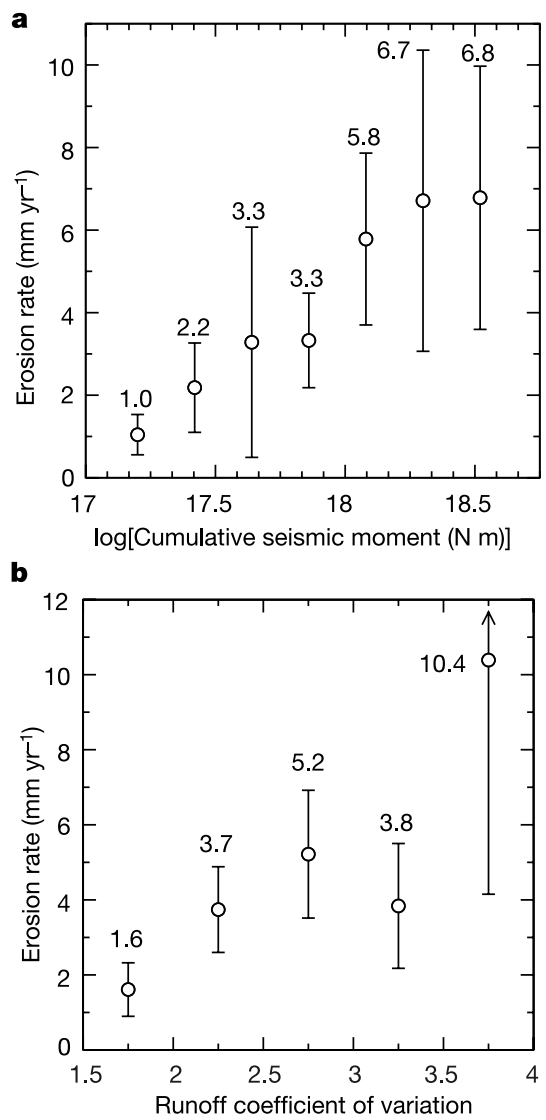

Figure 4 Correlations between erosion rates and their controls. a, Drainage-basin-wide suspended-sediment erosion rate as a function of cumulative scalar seismic moment, $M_{0}$. In total 128 drainage basins are shown (two extreme outliers were removed), binned by mean cumulative seismic moment release within their boundaries. $\mathbf{b}$, Drainage-basinwide suspended-sediment erosion rate as a function of coefficient of runoff variation. In total, 128 drainage basins are shown (two extreme outliers were removed), binned by the coefficient of runoff variation defined by their water discharge record. For $\mathbf{a}$ and $\mathbf{b}$, the mean erosion rates within these bins are shown, and their 95\% confidence intervals. 
the northern Central Range, but subdued in Pliocene-Quaternary sediments of the Western Foothills thrust belt. Across Taiwan, compressive strength correlates with average slope $\left(r^{2}=0.31\right)$ and basin relief $\left(r^{2}=0.17\right)$. The highest erosion rates are in lowrelief terrain with weak substrate. This reinforces the notion that substrate properties modulate the topographic expression of tectonic deformation and erosion. Determining erosion rates from topography is possible only when spatially variable substrate erodibility is taken into account.

In summary, progressive exhumation of competent rocks at rates up to $3-6 \mathrm{~mm} \mathrm{yr}^{-1}$ has built a high and steep mountain belt in Taiwan. Holocene river incision rates are highest on active faults. Erosion modifies the topographic expression of active faults to a degree determined by the strength of the exposed substrate. The decadal erosion pattern is strongly associated with production of sediment by landsliding during large earthquakes and storms. Modern erosion follows changing patterns of seismic deformation, suggesting that future erosion rates in north and central Taiwan will be elevated following the $1999 M_{\mathrm{w}}=7.6$ Chi-Chi earthquake.

\section{Methods}

\section{River sediment load}

At each hydrometric station, water discharge was measured daily and suspended sediment concentration was measured at an average frequency of 24 samples per year using a USDH-48 depth-integrating suspended sediment sampler ${ }^{23}$ (Supplementary Fig. Sla). We used a bias-corrected average of the reported measurements to obtain time-averaged suspended sediment loads ${ }^{24}$. This method corrects for the increased number of observations in the summer months. An alternative approach using a rating curve between water and suspended sediment discharge is not appropriate for most rivers in Taiwan because it assumes that rivers are transport-limited. In Taiwan, most catchments have a strong supply-limited component ${ }^{9}$, so a direct average as used here is the most appropriate method for estimating suspended sediment discharge ${ }^{24}$. To obtain a stable measure of erosion we used only observations from the 130 gauging stations with records spanning at least eight years. Catchment-wide erosion rates were calculated from annual suspended sediment discharge by dividing by the density of quartz and by drainage area. For catchments that had several nested gauges we recalculated erosion rates for the parts with multiple gauges, using data from each upstream station. Our analysis extends until the end of August 1999, excluding the effects of the Chi-Chi earthquake. At present the onward transport of material produced during the Chi-Chi earthquake is incomplete. Extension of our analysis to the end of 2001 would lead to a $12 \%$ increase in our estimate of the annual average suspended sediment discharge from Taiwan. We do not consider chemical erosion rates, which are probably an order of magnitude lower than physical erosion rates ${ }^{12}$ and are poorly constrained.

\section{Channel incision rates}

Bedrock incision rates were obtained by dating organic material deposited on strath terraces formed as rivers incised through their bedrock substrate. Measurements are from bedrock terraces overlain by less than five metres of channel deposit. Radiometric ages were calculated from ${ }^{14} \mathrm{C}$ in wood or plant fragments in the alluvial veneer, and converted to calendar ages ${ }^{25}$. Incision rates were calculated by dividing the elevation of the bedrock terrace above the modern river by the calendar age. Uncertainties were calculated as $1 \sigma$ for age and as $20 \%$ for terrace elevation, the latter to account for variations in river stage.

\section{Fission track ages and exhumation rates}

Long-term exhumation rates were obtained from apatite fission track ages. Fissioninduced damage tracks in apatite are annealed at million-year timescales at temperatures over $110^{\circ} \mathrm{C}$, so that fission track ages reflect cooling associated with exhumation from depths of $3-5 \mathrm{~km}$. The exhumation rates in Fig. $2 \mathrm{c}$ were determined using published ages from the Central Range ${ }^{15}$ and unpublished ages from the Western Foothills thrust belt, interpreted through a thermal model with one-dimensional heat transfer, an initial geothermal gradient of $25^{\circ} \mathrm{C} \mathrm{km}^{-1}$, a surface temperature of $10^{\circ} \mathrm{C}$ and a constant erosion rate. Lacking an independent estimate of the duration of exhumation, we use the first occurrence of reset ages at the surface. This assumption provides a maximum estimate of exhumation rate. If geothermal gradients are higher owing to a greater duration of exhumation or conductive focusing of heat into valleys where samples were primarily obtained, the inferred exhumation rates would be lower.

\section{Stream power erosion index}

Stream power per unit area of bed, $\omega\left(\mathrm{Wm}^{-2}\right)$, can be written ${ }^{26,27}$ as $\omega=\rho g Q S / w$, where $\rho$ is water density $\left(1,000 \mathrm{~kg} \mathrm{~m}^{-3}\right), g$ is acceleration due to gravity $\left(9.8 \mathrm{~m} \mathrm{~s}^{-2}\right), Q$ is water discharge $\left(\mathrm{m}^{3} \mathrm{~s}^{-1}\right), S$ is channel slope, and $w$ is channel width (m). An index of erosion potential based on stream power can be constructed using a combination of river discharge data and attributes derived from a digital elevation model (DEM $)^{21,22}$. We computed unit stream power using a 40-m resolution DEM to measure slope in the direction of steepest descent. Runoff was estimated from water discharge measurements and annual discharge was calculated for each point in the DEM by integrating runoff upslope. Channel width cannot be resolved using a DEM of this scale, so we used its scaling relation with discharge $\left(w \propto Q^{0.5}\right)$ to rewrite unit stream power as $\omega=\rho g Q^{0.5}$. This is confirmed for Taiwan by measurements of channel width from a 5-m resolution satellite image at 12 gauging stations in central Taiwan.

Received 23 May; accepted 21 October 2003; doi:10.1038/nature02150.

1. Koons, P. O. The topographic evolution of collisional mountain belts: A numerical look at the Southern Alps, New Zealand. Am. J. Sci. 289, 1041-1069 (1989).

2. Beaumont, C., Fullsack, P. \& Hamilton, J. in Thrust Tectonics (ed. McClay, K. R.) 1-18 (Chapman and Hall, London, 1992).

3. Willett, S. D. Orogeny and orography: the effects of erosion on the structure of mountain belts. J. Geophys. Res. 104, 28957-28981 (1999).

4. Milliman, J. D. \& Syvitsky, J. P. M. Geomorphic/tectonic control of sediment discharge to the ocean: The importance of small mountainous rivers. J. Geol. 100, 525-544 (1992).

5. Teng, L. S. Geotectonic evolution of late Cenozoic arc-continent collision in Taiwan. Tectonophysics 183, 57-76 (1990).

6. Liew, P. M. et al. Holocene tectonic uplift deduced from elevated shorelines, eastern Coast Range of Taiwan. Tectonophysics 222, 55-68 (1993).

7. Liu, T. K. Tectonic implications of fission-track ages from the Central Range, Taiwan. Proc. Geol. Soc. China 25, 22-37 (1982).

8. Shieh, S. L. et al. Users' Guide for Typhoon Forecasting in the Taiwan Area (VIII) (Central Weather Bureau, Taipei, 2000).

9. Hovius, N., Stark, C. P., Chu, H. T. \& Lin, J. C. Supply and removal of sediment in a landslidedominated mountain belt: Central Range, Taiwan. J. Geol. 108, 73-89 (2000).

10. Hartshorn, K., Hovius, N., Dade, W. B. \& Slingerland, R. L. Climate-driven bedrock incision in an active mountain belt. Science 297, 2036-2038 (2002).

11. Water Resources Agency. Hydrological Yearbook of Taiwan, Republic of China (Ministry of Economic Affairs, Taipei, 1970-2001); at 〈http://gweb.wra.gov.tw/wrweb/〉.

12. Li, Y. H. Denudation of Taiwan island since the Pleistocene epoch. Geology 4, 105-107 (1976).

13. Fuller, C. W., Willett, S. D., Hovius, N. \& Slingerland, R. Erosion rates for Taiwan mountain basins: New determinations from suspended sediment records and a stochastic model of their temporal variation. J. Geol. 111, 71-87 (2003).

14. Hsieh, M. L. \& Knuepfer, P. L. K. Middle-late Holocene river terraces in Erjen River basin, southwestern Taiwan-implications of river response to climate change and active tectonic uplift. Geomorphology 38, 337-372 (2001).

15. Willett, S. D., Fisher, D., Fuller, C., Yeh, E. C. \& Lu, C. Y. Erosion rates and orogenic wedge kinematics in Taiwan inferred from apatite fission track thermochronometry. Geology 31, 945-948 (2003).

16. Hickman, J. B., Wiltschko, D. V., Hung, J. H., Fang, P. \& Bock, Y. in Geology and Geophysics of an ArcContinent Collision, Taiwan (eds Byrne, T. B. \& Liu, C. S.) 75-92 (Geological Society of America Special Paper 358, GSA, Boulder, CO, 2002).

17. Hsieh, M. L. \& Knuepfer, P. L. K. in Geology and Geophysics of an Arc-Continent Collision, Taiwan (eds Byrne, T. B. \& Liu, C. S.) 55-74 (Geological Society of America Special Paper 358, GSA, Boulder, CO, 2002).

18. Liew, P. M., Kuo, C. M., Huang, S. Y. \& Tseng, M. H. Vegetation change and terrestrial carbon storage in eastern Asia during the Last Glacial Maximum as indicated by a new pollen record from central Taiwan. Glob. Planet. Change 16-17, 85-94 (1998).

19. Keefer, D. K. Landslides caused by earthquakes. Geol. Soc. Am. Bull. 95, 406-421 (1984).

20. Yu, S. B., Chen, H. Y. \& Kuo, L. C. Velocity field of GPS stations in the Taiwan area. Tectonophysics 274, 41-59 (1997).

21. Montgomery, D. R., Balco, G. \& Willett, S. D. Climate, tectonics, and the morphology of the Andes. Geology 27, 579-582 (2001)

22. Finlayson, D. P., Montgomery, D. R. \& Hallet, B. Spatial coincidence of rapid inferred erosion with young metamorphic massifs in the Himalayas. Geology 30, 219-222 (2002).

23. Kao, S. J. \& Liu, K. K. Estimating the suspended sediment load by using the historical hydrometric record from the Lanyang-Hsi watershed. Terrestr. Atmos. Oceanic Sci. 12, 401-414 (2001).

24. Cohn, T. A. Recent advances in statistical methods for the estimation of sediment and nutrient transport in rivers. Rev. Geophys. 33(suppl.) 1-18 (1995).

25. Stuiver, M. \& Raimer, P. J. Extended ${ }^{14} \mathrm{C}$ data base and revised CALIB $3.0^{14} \mathrm{C}$ age calibration program. Radiocarbon 35, 215-230 (1993).

26. Bagnold, R. A. The flow of cohesionless grains in fluids. Phil. Trans. R. Soc. Lond. A 249, 335-397 (1956)

27. Whipple, K. X. \& Tucker, G. E. Dynamics of the stream-power river incision model: Implications for height limits of mountain ranges, landscape response timescales, and research needs. J. Geophys. Res. 104, 17661-17674 (1999).

28. Ho, C. S. An Introduction to the Geology of Taiwan: Explanatory Text of the Geological Map of Taiwan 2nd edn (Central Geological Survey, Ministry of Economic Affairs, Taipei, 1986).

29. Carena, S., Suppe, J. \& Kao, H. Active detachment of Taiwan illuminated by small earthquakes and its control of first-order topography. Geology 30, 935-938 (2002).

30. Ekström, G. \& Dziewonski, A. M. Evidence of bias in the estimation of earthquake size. Nature 332, 319-323 (1988).

Supplementary Information accompanies the paper on www.nature.com/nature.

Acknowledgements This work was supported by the UK Natural Environment Research Council with a CASE addition from Faber Maunsell plc, and by the Taiwan National Science Council, and the Royal Society. We thank P. Molnar and D. Burbank for constructive reviews, and N. Lang and S. Pegg for assistance with data analysis.

Competing interests statement The authors declare that they have no competing financial interests.

Correspondence and requests for materials should be addressed to S.J.D

(simon00@esc.cam.ac.uk). 